\title{
The Predietive Signifieance of Some Kinematical Parameters On the Record Level of Male and Female Shot Put Competitors Under the Age of 18.
}

\section{Walid Soliman Ismail Elsaidy}

Department of Fundamentals of Physical Education, Faculty of Physical Education for Men, Alexandria University, Egypt.

\begin{abstract}
The aim of this study is to identify the relationship between some kinematical variables and the shot put distance of the male and female competitors under the age of 18 years, who participated in the republic championship season 2013, As well as to identify the contribution of the most important kinematic variables on the achieved shot put distance. The research sample consisted of 31 male and 21 female. The researcher has used the descriptive methodology with survey method through video, and motion analysis. Through the procedures of this research and the obtained results, it has been found that there are statistically significant correlations between the achieved shot put distance and some kinematic variables - (acceleration distance, height of release point and velocity of release) - for the male competitors. As well as, the results have shown that there are statistically significant correlations between the achieved shot put distance and some kinematic variables of - (acceleration, height of release point, angle of release, angle of launching and velocity of release) - for the female competitors. The velocity of release is the most important and contribution variable with the achieved shot put distance for male and female competitors. In light of results, the researcher has been reached two equations to predict the achieved shot put distance, this equations Depends on the velocity of release variable.
\end{abstract}

\section{Introduction:}

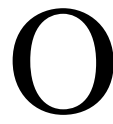
ver the last few years, Track and Field competitions have acquired a great position in the world, they have been using the scientific techniques as means to break the records, and the evaluation process as a method to identify the strong and weakness points of the athletes and training programs. Evaluation is considered one of the important processes in the physical education in order to appraise the player's ability and try to improve his performance.

Scientific progress requires us to get rid of the nonobjective estimations of the motor examination in the sports activities, and to appraise the motor performance by using a sound scientific methods in order for preparing the training programs, as well as solving the problems that may intercept the sports accomplishments. (4)

Since all the movements are connected to the mechanical laws, Biomechanics is considered one of the principal sciences that appraise the sports movements, and solve the problems that related to the motor performance. The motor analysis is an evaluator method that help the teachers and coaches to discover the problems and correct them in light of specific considerations for the performance specifications. (11)

In addition, the motor analysis is considered one of the most important sciences that contribute to the athletics field through identifying the technical information. This information helps the coaches to understand the player's performance in light of a group of information that contribute to identifying the required motor procedures to accomplish this performance with high efficiency. (6)

Despite the studies that have been performed to develop the different training aspects for various sports, there are many problems that need to study and analyze. Problems of body mechanics depends on the accurate measurement and mathematical formulas to classify the information that is obtained by the motor analysis for the player's performance. The information that related to the different skills and motor performance have a great effect on the development of any sports activity in general, and technical performance in particular. This information is used to understand in what way the performance is executed, and discover the overlapping relations between the body movements and this performance. As well as, it is used to identify the required motor procedures to accomplish this performance with high efficiency. The scientific method is the process that is used to establish the principles of sports renaissance, and help the players to reach the highest levels. The scientific research has the ability to achieve the best results which could be applied in the practical field in order to increase and develop the effectiveness of player's performance. (7) (1)

Mastering and improvement of the skilled performance are related to the validity of minutiae of partial movement and how they are united. Thus, the different body movements are united and joined together in an entire system in order to form a complete motor behaviors. In general, the motor 
performance could not be executed with an excellent way unless it is researched an analyzed from various sides in light of laws and principles of mechanics, in order to achieve the excellence of motor performance and best results. It is necessary for coaches and teachers to understand and analyze the causes of movements. The biomechanical analysis is considered one of the principal aspects in scientific diagnosis in order to employ the technical performance of motor skills through applying the mechanical bases and laws that control the human body. (8) (12) (2) (13)

Shot put is one of the activities that are related to the mechanical considerations which have a great effect on the achieved horizontal distance. The technical performance of shot put competition is complicated and depends on biomechanical characteristics such as the initial velocity of shot put, angle of shot put and height of release point. The technical performance also depends on the motor characteristics like the good motor transmission for the power and momentum. (5) (10)

Many studies refer to that it is necessary for the shot put competitors to combine the different biomechanical variables such as speed of release, angle of release and height of release point in order to achieve the best horizontal distance.

(28) ( 23)

In addition There are many Arabian and foreign studies [Maheras, A.V. (1995), Alexander, M.J etc. (1996), K Bartonietz (1996), Hubbard, M., etc. all (2001), Linthorne, N.P. (2001), Young, M., \& Li, L (2005) and Young, M (2004)] that have discussed the biomechanical characteristics of shot put, as well as the most effective factors in the competition. (24) (14) (15) (20) (22) (29) (31)

However, the previous studies were not applied on the Egyptian emerging players because of the Egyptian training reality, and the technical aspect of the Egyptian female and male players. So, this research is a trial for introducing enough information for the coaches and teachers about the most effective biomechanical variables on the shot put distance. As well as, the researcher tries to reach a predictive formula that helps the coaches to appraise the player's performance, and follow the effectiveness of training programs that are directed towards the most effective biomechanical variables. On the local and national level, Shot put competition suffers from many problems that affect the achievement level. The coaches' carelessness leads to a decrease in the players' performance and the level of competition. In addition, the most important problem that shot put faces that the coaches often depend on subjective evaluation through observation rather than the sound scientific evaluation.

Therefore, the researcher has tried to provide an objective evaluation process for the kinematic variables in order to develop the technical performance of shot put, as well as identify the most effective variables on the achieved shot put distance. Through the process of analysis and evaluation, it is possible to obtain a significant information about the level and performance of emerging players, in order for preparing them in light of the scientific bases. The researcher seeks to introduce an objective scientific means for evaluation, which could be used in the training programs and comparison processes of the players' levels. Eventually, this leads to modify the training methodology in order to fit with the required level, and achieve the desired progress from the training process.

\section{Research Objectives}

1. Identifying the relation between the values of kinematic variables and the achieved shot put distance of male and female competitors under the age of 18 , who participated in the republic championship season 2013.

2. Identifying percentage of effect of the most important kinematic variables on the achieved shot put distance of male and female competitors under the age of 18, who participated in the republic championship season 2013.

\section{Research Hypotheses}

1. There is statistically significant correlation between the kinematic variables under research and the achieved shot put distance of male and female competitors under the age of 18 , who participated in the republic championship season 2013.

2. Kinematic variables under research contribute, in different percentages, to the achieved shot put distance of male and female competitors under the age of 18 , who participated in the republic championship season 2013.

\section{Research Procedures}

\section{$\underline{\text { Research Methodology }}$}

The researcher has used the descriptive survey method, by using video imaging and biomechanical analysis, because it is appropriate for the objective and nature of research.

\section{Research Domains}




\section{$\underline{\text { Human Domain }}$}

The research's sample was selected with random method from the male and female shot put competitors, who participated in the republic championship and the tests of national team at season 2013. The sample consisted of 52 competitors who were divided into 31 male and 21 female under the age of 18. This sample was selected for the following reasons:

1. The kinematic aspect of this research deals with the best trials of competitors.

2. Those players were considered to be the best in this age stage.

3. Those players kept training continuously, and participated in regional and international championships.

Time Domain

The measurements were implemented in the sports season 2013, during the Cup Championship and tests of national team, in the period from $16 / 3 / 2013$ to $28 / 4 / 2013$.

Spatial Domain

Athletics Court, Olympic Center Maadi, Cairo.

\section{Exploratory Study}

This exploratory study was implemented in order to:

1. Choose the best site for the camera in order to show all the stages of performance from beginning to end.

2. Choose the necessary instruments to perform the measurements of research.

3. Check the validity and accuracy of instruments.

4. Set a general plan that takes logical order into consideration to perform the measurements of research.

5. Determine the number of assistants, and train them on how to perform the measurements.

6. Identifying the errors that probably appear during the implementation.

7. Check the appropriateness of measurements form.

\section{Measurements and Tests}

Firstly: primary measurements

- $\quad$ Age to the nearest (month).

- Weight to the nearest (Kilogram).

- $\quad$ Length to the nearest (Centimeter).

Secondly: Kinematic Variables
In light of the reference survey and previous studies, the researcher has determined a group of kinematic variables in order to identify their effect on the shot put distance.

- Acceleration distance

- Acceleration time

- Acceleration

- Height of release point

- Angle of release

- Angle of launching

- Velocity of release

\section{Tools and Instruments}

1. Two Videos Cameras with frequency $30 \mathrm{fps}$.

2. Two tripods.

3. Four butteries for the cameras.

4. Tape measure.

5. Phosphoric marks to determine the anatomical areas.

6. Measurement girder to determine scale drawing.

7. Circle for shot put throwing.

8. Shot puts.

9. Restameter to measure length to the nearest (Centimeter).

10. Medical scale to measure weight to the nearest (Kilogram).

\section{Preparing the place for imaging}

1. Fixing the cameras above the tripods with water balance.

2. Making sure there is no deflection on the level of imaging.

3. Determining the dimensions of imaging place in light of the results of exploratory study.

4. Check the degree of lighting in the place.

5. The distance between the side camera and the middle section is 5.70 meter, and the height of side camera from the ground is 1.15 meter. The distance between the center of shot put circle and the forward camera is 25 meter, and the height of forward camera from the ground is 1.15 meter.

Assistants

1. Two referees to measure the legal distance of long jump for each player.

2. One assistant to operate the camera.

3. One assistant to write down the player's name, his legal distance, and the number of his trial.

4. One assistant to call for the player and his number of trial.

\section{Imaging Procedures}

All the trials of male and female competitors, in the republic championship and national team qualification, 
were recorded. It was accounted only the best trial for both male and female competitors.

\section{Analysis Procedures}

The researcher has performed the following procedures:

1. Entering the digital video images into the computer, especially the best trial that the player recorded.

2. Presenting the video tape that shows the player's trials to analyze them according to the registration form.

3. Analyzing the best players' trials by using the motor analysis program (Video Point) in order to calculate the values of chosen kinematic variables.

\section{Presentation \& Discussion of Results}

\section{First: Presentation of Results}

\section{Table (1)}

Statistical description of male shot put competitors under the age of 18 , in the measurements of age, length, weight, and kinematic indicators under research, as well as shot put distance $(\mathbf{N}=\mathbf{3 1})$

\begin{tabular}{|c|c|c|c|c|c|c|c|c|c|c|c|}
\hline $\begin{array}{r}\text { Statistica } \\
\text { Signifi }\end{array}$ & asurements & 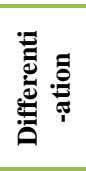 & $\sum_{\Sigma}^{\text {⿷匚 }}$ & 总 & 疍 & $\frac{0}{0}$ & 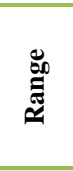 & $\frac{\mathscr{E}}{d}$ & 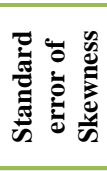 & $\frac{n}{0}$ & 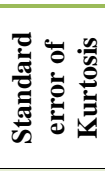 \\
\hline \multirow{3}{*}{$\begin{array}{c}\text { Primary } \\
\text { Measure- } \\
\text { ments }\end{array}$} & Age & Year & 15.53 & 1.60 & 16.00 & 17.00 & 5.00 & -0.16 & \multirow{11}{*}{0.42} & -1.18 & \multirow{11}{*}{0.82} \\
\hline & Length & Meter & 1.75 & 0.10 & 1.77 & 1.60 & 0.32 & 0.01 & & -1.19 & \\
\hline & Weight & $\mathrm{Kg}$ & 79.60 & 15.22 & 76.00 & 73.00 & 51.00 & 0.58 & & -0.64 & \\
\hline \multirow{7}{*}{ 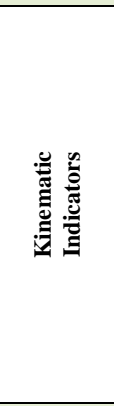 } & $\begin{array}{c}\text { Acceleration } \\
\text { Distance }\end{array}$ & $\mathrm{cm}$ & 1.32 & 0.19 & 1.27 & 1.62 & 0.74 & 0.56 & & -0.52 & \\
\hline & $\begin{array}{c}\text { Acceleration } \\
\text { Time } \\
\end{array}$ & $\mathrm{S}$ & 0.24 & 0.06 & 0.23 & 0.20 & 0.24 & 0.56 & & -0.02 & \\
\hline & Acceleration & $\mathrm{m} / \mathrm{s}$ & 5.82 & 1.32 & 5.70 & 7.06 & 5.13 & 0.11 & & -0.45 & \\
\hline & $\begin{array}{c}\text { Height of } \\
\text { release point }\end{array}$ & Meter & 1.95 & 0.10 & 1.94 & 1.87 & 0.43 & 0.49 & & 0.12 & \\
\hline & $\begin{array}{c}\text { Angle of } \\
\text { release }\end{array}$ & Degree & 35.65 & 8.04 & 35.00 & 39.00 & 38.00 & 0.22 & & 0.68 & \\
\hline & $\begin{array}{c}\text { Angle of } \\
\text { launching }\end{array}$ & Degree & 31.06 & 6.21 & 31.00 & 32.00 & 30.00 & 0.54 & & 1.02 & \\
\hline & $\begin{array}{c}\text { Velocity of } \\
\text { release }\end{array}$ & $\mathrm{m} / \mathrm{s}$ & 9.07 & 1.67 & 9.22 & 5.46 & 6.36 & -0.40 & & -0.26 & \\
\hline \multicolumn{2}{|c|}{ Shot put distance } & Meter & 12.53 & 3.42 & 12.12 & 12.90 & 14.42 & 0.62 & & 0.86 & \\
\hline
\end{tabular}

From table (1), it is clarified that all the values of Skewness and Kurtosis are less than the square of standard error. These results indicate to the normality of variables'

\section{Statistical processing}

The researcher has used the statistical processing to achieve the research's objectives, by using the statistical program (SPss):

1. Arithmetic Mean

Skewness

2. Standard Deviation Kurtosis

3. Median

Coefficient of Variance

4. Mode

9. Test of simple correlation

5. Range .

Regression coefficient (Stepwise) 


\section{Table (2)}

Statistical description of female shot put competitors under the age of 18, in the measurements of age, length, weight, and kinematic indicators under research, as well as shot put distance $(\mathbf{N}=\mathbf{2 1})$

\begin{tabular}{|c|c|c|c|c|c|c|c|c|c|c|c|}
\hline $\begin{array}{l}\text { Statistical } \\
\text { Significa }\end{array}$ & Ieasurements & 竘 & 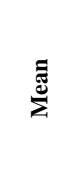 & 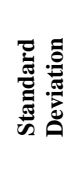 & t: & $\frac{\pi}{2}$ & 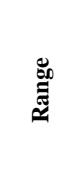 & 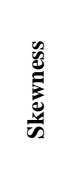 & 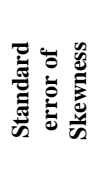 & 章 & 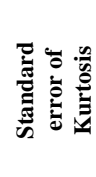 \\
\hline \multirow{3}{*}{$\begin{array}{c}\text { Primary } \\
\text { Measure- } \\
\text { ments }\end{array}$} & Age & Year & 14.95 & 1.66 & 14.00 & 17.00 & 4.00 & 0.23 & \multirow{11}{*}{0.50} & -1.70 & \multirow{11}{*}{0.97} \\
\hline & Length & Meter & 1.65 & 0.06 & 1.66 & 1.65 & 0.21 & -0.16 & & -0.66 & \\
\hline & Weight & $\mathrm{Kg}$ & 71.52 & 12.82 & 74.00 & 74.00 & 53.00 & 0.71 & & 1.17 & \\
\hline \multirow{7}{*}{ 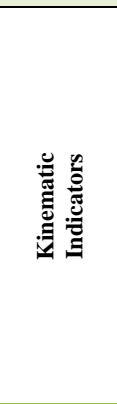 } & $\begin{array}{l}\text { Acceleration } \\
\text { Distance }\end{array}$ & $\mathrm{cm}$ & 1.34 & 0.18 & 1.39 & 1.39 & 0.66 & -0.36 & & -0.48 & \\
\hline & $\begin{array}{c}\text { Acceleration } \\
\text { Time }\end{array}$ & S & 0.29 & 0.07 & 0.26 & 0.33 & 0.26 & 0.84 & & 0.51 & \\
\hline & Acceleration & $\mathrm{m} / \mathrm{s}$ & 4.69 & 0.78 & 4.65 & 3.41 & 2.72 & 0.17 & & -0.67 & \\
\hline & $\begin{array}{l}\text { Height of } \\
\text { release point }\end{array}$ & Meter & 1.83 & 0.07 & 1.82 & 1.89 & 0.26 & 0.13 & & -0.71 & \\
\hline & $\begin{array}{c}\text { Angle of } \\
\text { release }\end{array}$ & Degree & 35.19 & 5.19 & 36.00 & 37.00 & 20.00 & -0.32 & & 0.19 & \\
\hline & $\begin{array}{r}\text { Angle of } \\
\text { launching }\end{array}$ & Degree & 30.14 & 5.87 & 30.00 & 34.00 & 25.00 & 0.37 & & 0.70 & \\
\hline & $\begin{array}{l}\text { Velocity of } \\
\text { release }\end{array}$ & $\mathrm{m} / \mathrm{s}$ & 8.67 & 1.22 & 8.63 & 10.18 & 4.16 & -0.29 & & -.072 & \\
\hline \multicolumn{2}{|c|}{ Shot put distance } & Meter & 10.63 & 2.77 & 9.50 & 6.55 & 9.70 & 0.41 & & -0.83 & \\
\hline
\end{tabular}

From table (2), it is clarified that all the values of Skewness and Kurtosis are less than the square of standard error. These results indicate to the normality of variables'

\section{Table (3)}

Matrix of correlation coefficients between the values of kinematic indicators under research and shot put distance for male shot put competitors under the age of $18(\mathbf{N}=\mathbf{3 1})$

\begin{tabular}{|c|c|c|c|c|c|c|c|c|c|}
\hline Correlation & & 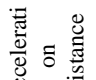 & 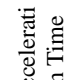 & Acceleration & 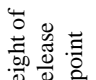 & 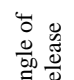 & 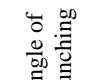 & 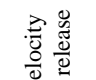 & 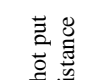 \\
\hline Acceleration & $\mathrm{R}$ & 1 & $* 0.395$ & 0.121 & 0.266 & -0.117 & -0.49 & $* * 0.562$ & $* * 0.456$ \\
\hline Distance & Sig. & & 0.028 & 0.517 & 0.148 & 0.531 & 0.792 & 0.001 & 0.010 \\
\hline Acceleration & $\mathrm{R}$ & & 1 & $* *-0.831$ & -0.191 & -0.202 & -0.059 & 0.148 & 0.068 \\
\hline Time & Sig. & & & 0.000 & 0.304 & 0.275 & 0.751 & 0.428 & 0.717 \\
\hline Acceleration & $\mathrm{R}$ & & & 1 & 0.342 & 0.233 & 0.056 & 0.089 & 0.124 \\
\hline & Sig. & & & & 0.060 & 0.207 & 0.763 & 0.634 & 0.508 \\
\hline Height of & $\mathrm{R}$ & & & & 1 & 0.340 & 0.278 & $* * 0.539$ & $* * 0.580$ \\
\hline release point & Sig. & & & & & 0.061 & 0.130 & 0.002 & 0.001 \\
\hline Angle of & $\mathrm{R}$ & & & & & 1 & $* * 0.470$ & -0.015 & 0.023 \\
\hline release & Sig. & & & & & & 0.008 & 0.937 & 0.0902 \\
\hline Angle of & $\mathrm{R}$ & & & & & & 1 & 0.330 & 0.211 \\
\hline launching & Sig. & & & & & & & 0.070 & 0.254 \\
\hline Velocity of & $\mathrm{R}$ & & & & & & & 1 & $* * 0.874$ \\
\hline release & Sig. & & & & & & & & 0.000 \\
\hline Hishest Triol & $\mathrm{R}$ & & & & & & & & 1 \\
\hline НाЕ & Sig. & & & & & & & & \\
\hline
\end{tabular}

values, which are considered one of the conditions for performing correlation and regression.

* Significant $\mathbf{r}$ at 0.05 level $=0.0355$

$* *$ Significant $\mathbf{r}$ at 0.01 level $=0.456$ 
From table (3), it is clarified that there are correlations between shot put distance and the variables of acceleration distance, height of release and velocity of release. The

\section{Table (4)}

Matrix of correlation coefficients between the values of kinematic indicators under research and shot put distance for female shot put competitors under the age of $18(\mathbf{N}=\mathbf{2 1})$

\begin{tabular}{|c|c|c|c|c|c|c|c|c|c|}
\hline Correlation & & 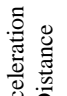 & 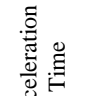 & 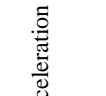 & 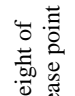 & 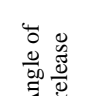 & 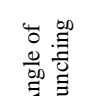 & 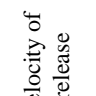 & 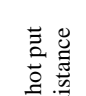 \\
\hline Acceleration & $\mathrm{R}$ & 1 & $* 0.615$ & 0.044 & 0.223 & 0.237 & 0.044 & 0.224 & 0.113 \\
\hline Distance & Sig. & & 0.003 & 0.851 & 0.332 & 0.300 & 0.851 & 0.328 & 0.627 \\
\hline Acceleration & $\mathrm{R}$ & & 1 & $* *-0.743$ & -0.117 & 0.003 & -0.175 & -0.353 & -0.331 \\
\hline Time & Sig. & & & 0.000 & 0.613 & 0.991 & 0.447 & 0.116 & 0.143 \\
\hline Acceleration & $\mathrm{R}$ & & & 1 & 0.374 & 0.115 & 0.200 & $* * 0.687$ & $* 0.543$ \\
\hline & Sig. & & & & 0.095 & 0.621 & 0.384 & 0.001 & 0.011 \\
\hline Height of & $\mathrm{R}$ & & & & 1 & -0.099 & 0.278 & $* 0.466$ & $* 0.450$ \\
\hline release point & Sig. & & & & & 0.670 & 0.223 & 0.033 & 0.041 \\
\hline Angle of & $\mathrm{R}$ & & & & & 1 & $* 0.516$ & 0.285 & $* 0.437$ \\
\hline release & Sig. & & & & & & 0.017 & 0.210 & 0.048 \\
\hline Angle of & $\mathrm{R}$ & & & & & & 1 & $* 0.545$ & $* 0.535$ \\
\hline launching & Sig. & & & & & & & 0.011 & 0.013 \\
\hline Velocity of & $\mathrm{R}$ & & & & & & & 1 & $* * 0.823$ \\
\hline release & Sig. & & & & & & & & 0.000 \\
\hline Hirhest Trial & $\mathrm{R}$ & & & & & & & & 1 \\
\hline Mignest Imal & Sig. & & & & & & & & \\
\hline
\end{tabular}

* Significant $\mathbf{r}$ at 0.05 level $=0.0355$

$* *$ Significant $\mathbf{r}$ at 0.01 level $=0.456$

From table (4), it is clarified that there are correlations between shot put distance and the variables of acceleration, height of release, angle of release, angle of

launching and velocity of release. The values of correlation coefficients are $* * 0.832, * 0.535, * 0.437$, $* 0.450, * * 0.580$, respectively.

Table (5)

This table lists multiple correlation, squared multiple correlation (percentage of total effect) and corrected correlation coefficient. As well as, it includes percentage of effect, partial regression coefficient, $(\mathrm{T})$ value and $(\mathrm{F})$ value, which is fit for the regression formula that related to the effect of kinematic indicators under research on the shot put distance for male shot put competitors under the age of 18 . $(\mathbf{N}=\mathbf{3 1})$

\begin{tabular}{|l|c|c|c|c|c|c|c|}
\hline \multicolumn{1}{|c|}{$\begin{array}{c}\text { Significances of } \\
\text { prediction }\end{array}$} & $\begin{array}{c}\text { Correlation } \\
\text { coefficient }\end{array}$ & $\begin{array}{c}\text { Total } \\
\text { Effect } \\
\text { Variables }\end{array}$ & $\begin{array}{c}\text { Corrected } \\
\text { correlation } \\
\text { coefficient } \\
\text { (Adjusted } \mathrm{R} \\
\text { square) }\end{array}$ & $\begin{array}{c}\text { Percentage of } \\
\text { effect }\end{array}$ & $\begin{array}{c}\text { Partial } \\
\text { regression } \\
\text { coefficient }\end{array}$ & $\begin{array}{c}\mathrm{T} \\
\text { Value }\end{array}$ & $\begin{array}{c}\mathrm{F} \\
\text { Value }\end{array}$ \\
\hline Velocity of release & 0.874 & 0.764 & 0.755 & $76.4 \%$ & 1.788 & $* * 9.676$ & $* * 93.632$ \\
\hline Value of Secant & \multicolumn{7}{|l|}{-3.704} \\
\hline
\end{tabular}

**Significant $\mathrm{T}$ value at 0.01 level $=2.75$

*Significant $\mathrm{T}$ value at 0.05 level $=2.04$ $* *$ Significant $\mathrm{F}$ value at 0.01 level $=7.60 \quad *$ Significant $\mathrm{F}$ value at 0.05 level $=4.18$

From table (5), it is clarified that velocity of release is the most effective variable on the shot put distance. This variable contributes 76.4 percent in shot put distance, and it is considered to be a great percentage.

\section{Predictive formula:}

From the listed results in the previous table, predictive formula of shot put distance could be formulated as the following: 


\section{Shot put distance $=[-3.704+(1.788 *$ velocity of release $)]$}

Table (6)

This table lists multiple correlation, squared multiple correlation (percentage of total effect) and corrected correlation coefficient. As well as, it includes percentage of effect, partial regression coefficient, $(\mathrm{T})$ value and $(\mathrm{F})$ value, which is fit for the regression formula that related to the effect of kinematic indicators under research on the shot put distance for female shot put competitors under the age of 18. $(\mathbf{N}=\mathbf{2 1})$

\begin{tabular}{|c|c|c|c|c|c|c|c|}
\hline $\begin{array}{c}\text { Significances of } \\
\text { prediction }\end{array}$ & $\begin{array}{c}\text { Correlation } \\
\text { coefficient } \\
\text { Variables }\end{array}$ & $\begin{array}{c}\text { Total } \\
\text { Effect } \\
(\mathrm{R})\end{array}$ & $\begin{array}{c}\text { Corrected } \\
\text { correlation } \\
\text { coefficient } \\
\text { (Adjusted } \mathrm{R} \\
\text { square) }\end{array}$ & $\begin{array}{c}\text { Percentage of } \\
\text { effect }\end{array}$ & $\begin{array}{c}\text { Partial } \\
\text { regression } \\
\text { coefficient }\end{array}$ & $\begin{array}{c}\mathrm{T} \\
\text { Value }\end{array}$ & $\begin{array}{c}\mathrm{F} \\
\text { Value }\end{array}$ \\
\hline Velocity of release & 0.823 & 0.678 & 0.661 & $67.8 \%$ & 1.869 & $* * 6.323$ & $* * 39.976$ \\
\hline Value of Secant & \multicolumn{7}{|l|}{-5.577} \\
\hline
\end{tabular}

**Significant $\mathrm{T}$ value at 0.01 level $=2.85$

*Significant $\mathrm{T}$ value at 0.05 level $=2.09$ $* *$ Significant $\mathrm{F}$ value at 0.01 level $=8.81 \quad *$ Significant $\mathrm{F}$ value at 0.05 level $=4.38$

From table (6), it is clarified that velocity of release is the most effective variable on the shot put distance. This variable contributes 67.8 percent in shot put distance, and it is considered to be a great percentage.

From the listed results in the previous table, predictive formula of shot put distance could be formulated as the following:

\section{Predictive formula:}

Shot put distance $=[-5.577+(1.869 *$ velocity of release)]

\section{Secondly: Discussion of Results}

From table (1) and (2), it is clarified that all the values of Skewness and Kurtosis are less than the square of standard error. These results indicate to the normality of variable values of Skewness and Kurtosis, which are considered one of the conditions for performing correlation and regression. (9)

As well as, from table (3), it is clarified that there are correlations between shot put distance and the variables of acceleration distance, height of release and velocity of release. The values of correlation coefficient are $* * 0.456$, $* * 0.580$ and $* * 0.874$, respectively.

Additionally, many of studies have referred to the importance of the previous variables and their relation with shot put distance. Acceleration distance helps the player to acquire an amount of power, which is exploited during the release process, as well as the height of release help the player effectively to achieve a great travel distance in case of executing with an appropriate angle of release. (27) (30) (18) (25)
The scientific studies refers to that the mass of shot put player needs a certain distance in order to move and acquire the required velocity. This distance must be suitable for the player to be able to achieve the required acceleration and velocity in order to accomplish the optimal performance. This principle clarifies the relation between the acceleration distance and achievement distance. (3)

The velocity of release has the greatest effect on the shot put distance. The higher velocity of release, the higher achieved horizontal distance is. The results of world champions refers to that their velocities of release range between 12.5 and $14.5 \mathrm{~m} / \mathrm{s}$ with a resultant distance ranges between 19 and 23 meter. (26) (21) (16)

From table (4), it is clarified that there are correlations between shot put distance and the variables of acceleration, height of release, angle of release, angle of launching and velocity of release. The values of correlation coefficients are $* * 0.832, * 0.535, * 0.437$, $* 0.450, * * 0.580$, respectively.

In order to achieve the mechanical goal and reach for a horizontal distance as far as possible, it is necessary for the player to put the shot with maximum velocity, appropriate angle of launching, and balanced components of force. Velocity of release is an effective part in the mechanical characteristics to determine the horizontal shot put distance. Acceleration is considered one of the most important indicators that related to the power and ability, which help the player to achieve higher velocity of release and thus higher horizontal distance.

(3) (17) (19)

From table (5) and (6), it is clarified that velocity of release is the most effective variable for the shot put 
distance of the male and female competitors. This variable contributes 76.4 and 67.8 percent for male and female competitors respectively in shot put distance, and it is considered to be a great percentage.

\section{Conclusions}

In light of the research's results, the researcher has concluded that:

There is statistically significant correlation between the achieved shot put distance and the variables of acceleration distance, height of release point and velocity of release for the male competitors under the age of 18 .

There is statistically significant correlation between the achieved shot put distance and the variables of acceleration, height of release, angle of release, angle of launching and velocity of release for the female competitors under the age of 18 .

Velocity of release is the most effective variable on the shot put distance.

\section{Recommendation}

In light of the research's results, the researcher recommends that:

Using the results of this research in the processes of training and education for the male and female shot put competitors.

The necessity of biomechanical aspects in the training processes, which have a great effect on the performance.

Performing more scientific studies on different ages of the male and female shot put players.

\section{References}

\section{First: Arabian References}

1. Gamal Alaa El-Din.(1980). "Laboratory Studies in the Biomechanics of Sports Movement", Dar El-Maaref, Cairo.pp.12,18.

2. Gamal Alaa El-Din.(1989). "Movements System \& How to Direct and Control them (Theories \& practices)", $3^{\text {rd }}$ Issue, Alexandria.pp.3-5.

3. Habib Taher, Zohir Maghoul and Abbas Abdel Hamza.(2007).“The Most Important Kinematic Variables and its Relation with the Performance of Shot put Players in Middle Euphrates", Journal of Science of Physical Education, 6th Issue, 2nd Volume, pp.79,84.
4. Sawsan Abdel Menaem \& others. (1977). "Biomechanics in Sports Field", Dar El-Maaref, Cairo, $1^{\text {st }}$ Volume, pp.45.

5. Saeb Alobydi \& Samir el-Hashmi.(1991). "Applied Biomechanics", Dar Al-Kotob for printing and Publishing, Mosul University,Iraq.pp.6,61.

6. Talha Hossam el-Din.(1993). "Biomechanics (Scientific, Theoretical and Applied Bases)", Dar El-Fekr Al-Araby, 1st Edition, Cairo,pp.5.

7. Talha Hossam El-Din.(1994)."Functional and Motor Bases for Sports Training”, Dar Al-Fekr Al-Araby, Cairo.pp.130.

8. Adel Abdel-Basir.(1998). "Introduction for analyzing the Three Dimensions of Human Body Movement in Sports Field", Book Center for Publishing, Cairo.pp.11.

9. Ezzat Abdel Hameed.(2011)."Educational and Psychological Statistics (Applications by using SPss 18 program)", Dar Al-Fekr Al-Araby, Cairo.pp.418.

10. Qassem Hussein \& Mofek Mageed elMoula.(1991). "Biomechanics”, Dar El-Hekma, Basra University, Iraq.pp.5.209.

11. Qassem Hussein \& Iman Shaker. (1998). "Research Methods in Motor Analysis", Dar AlFekr Al-Araby for Printing and Publishing, $1^{\text {st }}$ Edition, Jordan.pp.59.

12. Mohamed Brequa \& Khirya el-Soukri.(2002). "The Basic Principles of Biomechanics in Sports Field", Monchaet Al-Maaref, Alexandria.pp.18.

13. Mohamed Youssef el-Sheikh.(1983). "Biomechanics and its Applications", $2^{\text {nd }}$ Edition, Dar Al-Maaref, Cairo.pp.16.

\section{$\underline{\text { Second: English References }}$}

14. Alexander, M.J., Lindner, K.J., \& Whalen, M. (1996). Structural and biomechanical factors differentiating between male and female shot put athletes. Journal of Human Movement Studies, 30, pp. 103-146.

15. Bartonietz, K. (1996). Biomechanical aspects of the performance structure in throwing events. Modern Athlete and Coach, 34(2), 7-11.

16. Daniel Vecchio, Carmen Muller-Karger, Edgar Salazar,(2012). BIOMECHANICAL STUDY OF 
THE SHOT PUT AND ANALYSIS OF THE FLIGHT PHASE, 12th Pan-American Congress of Applied Mechanics January 02-06, 2012, Port of Spain, Trinidad, pp.32-39.

17. de Mestre, N. J. (1990). The Mathematics of Projectiles in Sport. Cambridge: Cambridge University Press, pp.112-124.

18. Hay, J.G. (1993). Biomechanics of Sports Techniques, 4th ed. Englewood Clips, NJ: Prentice-Hal.pp.34.

19. Hubbard, M. (2000). The flight of sports projectiles. In V. M. Zatsiorsky (Ed.) Biomechanics in Sport: Performance Enhancement and Injury Prevention, Oxford, Blackwell Science, Ltd, pp. 381-400.

20. Hubbard, M., de Mestre, N.J., \& Scott, J. (2001). Dependence of release variables in the shot put. Journal of Biomechanics, 34, pp. 449-456.

21. Lanka, J. (2000). Shot Putting. In V. Zatsiorsky, Biomechanics in sport: performance enhancement and injury prevention, Wiley-Blackwell. pp. 436455 .

22. Linthorne, N.P. (2001c). Optimum release angle in the shot put. Journal of Sports Sciences, 19(5), pp. 359-372.

23. Luthanen, P. (1998). A Preliminary Study of Rotational Shot Put Technique. XVIth Symposium of the International Society of Biomechanics in Sports, Kostanz, Germany, ISBS, pp.18.

24. Maheras, A.V. (1995). The relationship between the angle of release and the velocity of release in the shot-put, and the application of a theoretical model to estimate the optimum angle of release. Unpublished doctoral dissertation, Lawrence, KS, University of Kansas.pp.7-11.

25. Nicholas P. Linthorne. (2001). Optimum release angle in the shot put, Journal of Sports Sciences, $19,359-372$

26. Sugumar.C. (2014).: A Biomechanical Analysis of The Shot Put Performance. Global Journal for Research Analysis, Volume: 3 Issue: 5 May 2014. , ISSN No 2277 - 8160. Pp.302-314.

27. Terzis, G., Kyriazis, T., Karampatsos, G., \& Georgiadis, G. (2012). Muscle strength, body composition, and performance of an elite shot- putter. International Journal of Sports Physiology and Performance, 7(4), pp. 394-396.

28. Tsirakos, D.K., Barlett, R.M., \& Kollias, I.A. (1995). A comparative study of the release and temporal characteristics of shot put. Journal of Human Movement Studies, 28, pp. 227-242.

29. Young, M. (2004b). Critical factors for the shot put. Track Coach, 166, 5299-5304.

30. Young, M., \& Li, L. (2005). Athletics. Sports Biomechanics, 4(2), pp.131-148.

31. Young, M., \& Li, L. (2005a). Determination of critical parameters among elite female shot putters. Sports Biomechanics, 4(2), 131-148. 
